\title{
A dynamic citizenship education for the new public school
}

\section{Patricia White}

\begin{abstract}
Currently in the UK, citizenship provision is meagre and, where it appears in schools, is heavily biased towards the theoretical. The paper acknowledges that citizenship education needs a theoretical aspect but argues that the new public school should complement this with more dynamic, experiential learning.

The proposal focusses on a democratic way of managing political conflict, the complex practice of compromise. It considers three essential features of a good compromise: mutual respect, coping with seemingly second-best choices and recognising sacrifice. Drawing on these elements, it argues, the new public school can offer a dynamic citizenship education through its organisation, structure and ethos. In a supportive learning environment school students can learn attitudes of respect, empathy towards others and ways of dealing with conflict by non-violent means, develop social imagination in exploring creative and ingenious solutions to conflict and learn to cope, collegially, with disappointed hopes.
\end{abstract}

Currently in the UK, citizenship education provision in schools is meagre and, where it appears, is heavily biased towards theoretical knowledge (Carter, 2016; DfE, 2015; Franklin, 2017). Citizenship education needs a knowledge base, but the aim of the new public school should not be to produce future political theorists but to educate citizens to act politically, employing their knowledge and skills, with facility, in a variety of contexts. For this, political knowledge must go hand in hand with dynamic, experiential learning.

\section{Democratic values, sentiments, institutions and conflict}

A democratic society is distinguished by its fundamental values - concern for all, justice and freedom - which are the rationale for its institutions and procedures. The 
citizens supporting these institutions have deeply rooted sentiments or dispositions like respect for others, concern for justice and freedom, courage, honesty, empathy, social imaginativeness. The values and sentiments are the permanent animating core. The institutions and procedures vary across societies according to history and circumstances, and are always revisable in favour of a better realisation of the values (White 1983,1996). The relationship between democratic values, their supporting sentiments and contingent embodiments in practices and institutions can be illustrated by a specific feature of democratic politics - the practice of compromise.

At the heart of democratic politics is conflict: conflict among citizens and communities between the goods desired (e.g. in the UK leaving/ remaining in the EU, the desirability of a plural society) and conflict between possible ways of achieving goods (e.g. over policing policies, economic policies, defence policies). Such conflict is not unique to democratic societies. Human life with its conflicting incommensurable values makes such clashes and ways of managing them ubiquitous (Berlin 1997; Williams, 1981, 1985). In the face of such clashes, so-called 'strong' leaders of all political shades express exasperation with the messiness, muddle and uncertainty of democratic politics. But one formidable obstacle (not the only one) to the strong leader solution to conflict is the lack of wise and reliably benevolent despots. In their absence, the checks and balances of democratic procedures offer some protection against errors and faulty (whether ill-thought through or ill-intentioned) government policies. Messy or not, faced with political conflict democratic compromise may be the best option. 


\section{Wheeling, dealing and compromising}

Not every conflict resolution though takes the form of a morally acceptable democratic compromise. Morally unacceptable are 'rotten compromises', agreements 'to establish or maintain a regime of cruelty and humiliation' like slavery (Margalit, 2010, p89). Similarly, shoddy compromises, exchanging worthless goods for valuables, and shabby deals taking advantage of the weaker partner, are not democratic (Margalit, 2010, pp 3-4).

On the other hand, a win-win solution is a problem-solving solution to a conflict, not a compromise. Both parties gain over the status quo and neither side makes a sacrifice (see Bellamy on the 'traders' compromise, 1999, pp.96-98).

A compromise is a second-best solution (or worse) which involves sacrifices for both parties. In addition, there is a major distinction to be drawn between principled and pragmatic compromises (see e.g. Benjamin,1990; Bellamy,1999; Margalit, 2010; Wendt, 2016). A principled compromise might involve, after an armed conflict for instance, sacrificing justice for peace (Margalit, 2010, pp 79-88). Whilst in a pragmatic compromise members of a governing coalition might compromise on the number of houses to be built in a social housing programme, both sides agreeing to a figure which is a second-best to their preferred state of affairs.

\section{What is a democratic compromise?}

What kind of (principled or pragmatic) compromise would be an ethically acceptable democratic compromise? Two accounts of the 'good' (Bellamy, 1999, pp 94-102) or 'sanguine' compromise (Margalit, 2010, pp 41-54) suggest that it will have three 
main features: (i) the parties will show mutual respect; (ii) be prepared to accept second-best choices; and (iii) recognise sacrifices made. An essential part of school students' dynamic political education, as we shall see, will be an initiation into the active practice of compromise involving these three elements.

1.Showing mutual respect means treating the other party as an equal in the bargaining situation, a matter of relational equality, and acknowledging that their interests are legitimate (Gutmann and Thompson, 2012, p60; Margalit, 2010, pp 4144).

In some cases, before negotiations can begin, each party needs to recognise the other as a legitimate partner. Where governments, for instance, need to negotiate with a 'terrorist organisation', this will involve a process of recognising that those who have been enemies until now have legitimate concerns and must no longer be treated as enemies but as partners in a process, as, e.g., in the cases of Basque separatists and the Spanish government, Israel and Palestine, and the Unionists and Nationalists in Northern Ireland.

This is not a call for altruism towards the other party, nor for friendship, but for respect for them as legitimate partners. This means, concretely, making gestures of goodwill towards their participation in the process, including making attempts to show empathy (understanding their position from their point of view). It means avoiding the language of Good and Evil to describe the relationship with them but rather seeing them as rivals and potentially as partners in a co-operative problem-solving situation (Margalit, 2010, pp. 4344). 
2. Second, parties to the conflict must 'give up on the dream' and be prepared to accept a second-best solution (Margalit, 2010, p.46). Holding on to it can only lead to stalemate and renewed conflict. The parties need to set aside their dreams and sort out a feasible agreement, a second-best solution for both. But this is hard. In the case of conflicts over values like justice and peace it can seem to amount to an admission, for instance, that the values of justice and fairness are not worth fighting for.

What might induce the parties to set aside the principles which they and their followers have for years struggled to defend and settle for a second-best solution? They may do this, as in Northern Ireland, in the hope of a lasting peace after years of conflict. In the interests of an enduring peace, each side is prepared not to insist on everything they could claim, perhaps on historical grounds, to be their due. They do not totally abandon their concern for a just solution to the conflict, they just do not press it to the limit. Judiciously, often over many years of negotiations, they weigh the value of peace over justice within a whole network of ethical and empirical considerations. Within this network they will rely on a range of values - tolerance, respect, fairness, trying to see things from others' points of view, a concern to establish the relevant facts of the case, a presumption against settling matters by force, and so on. The compromise is seen, from this standpoint, as preserving the overall pattern of values and important concerns in one's life and in the group one is representing (Benjamin, 1990, p37). This is not behaving in an unprincipled way without regard for issues of justice and moral integrity, rather the opposite. Faced with the clash of the values of justice and peace, a fine judgement has been made that whilst the demands of justice are always pertinent, at this moment peace is the existential need (Margalit, 2010, pp.79-88). The situation is uncertain and morally complex. There is no rule book to offer guidance: a judgement must be made. Those involved draw collaboratively on their 
resources of empathy, social imagination and practical ingenuity, at the same time accepting that, despite their best efforts, their judgement may be faulty. They have rejected the alternative of continuing the conflict and chosen to make a compromise which, taking their whole set of ethical concerns into account in this complex situation, is not to be seen as losing their integrity but preserving it.

3.The third feature of a good compromise, the recognition of mutual sacrifice, is closely connected to the other two. Both parties need to have the significance of their dreams/aspirations acknowledged, as well as what it means to them to give them up. The sacrifices both sides make need to be mutually recognised, and acknowledged by other significant figures or agencies involved in the agreement.

This recognition is connected to the respect underlying a good compromise. Part of showing respect for the other party is attempting to understand, very specifically, what the sacrifices the compromise demands mean to them. Acknowledging these sacrifices cannot be just a matter of uttering words of sympathy, however deeply felt. It requires actions, typically offering significant concessions of one's own. This might involve (unpalatable) exchange of prisoner agreements (as in Northern Ireland and between Israel and Palestine). It is hard for a population that has suffered terrorist attacks to accept that a release of 'convicted murderers' is part of the price they have to pay for peace. This part of the process demands that those involved have a concern for fairness (burdens should not be disproportionate), respect for their fellow compromisers, empathy towards them, sensitivity to delicate concerns around the sacrifices and, in making their judgements, an imaginative and flexible approach to the possibilities for concessions. 
These are the three features of democratic compromise germane to its role in political education. Compromisers need essentially to be people of a certain sort. They need to be concerned to establish the relevant facts of the case which will cover, for instance, the ability to gather relevant knowledge and gain understanding about the issues, including the historical and cultural background to the conflict. They need to have respect for their fellow compromisers as well as other personal qualities: tolerance, fairness, a presumption against settling matters by force, a concern to see things from others' points of view, social imagination, sensitivity to the possibilities for flexibility and resourceful in finding ways round obstacles in reaching acceptable solutions, courage, honesty, patience and more. Where in political contexts the compromisers represent others, (the electorate, union members), those represented need to share these qualities and appreciate them.

People are not born compromisers. They need to acquire the knowledge to discern where compromise is required and how it might be achieved; and they need to be determined to follow that path. Putting the practice of compromise at the heart of a school's structures, organisation and ethos is a powerful way of launching that complex learning process. Even in a national school system in which much direction comes from central government, there is scope at individual school level for considerable participation by students in the shaping of its activities, life and culture. Decisions need to be made about the use and sharing of resources (sports facilities, halls for drama), timings of activities in the school day, ways of collectively celebrating the start or end of the school year, how to construct and implement policies to cope with incidents of bullying, policies about mobile phone use. With students involved in the school's organisation and daily running, it becomes a site for a dynamic democratic education. An everyday case of school decision-making 
shows how the three features of compromise - mutual respect, accepting secondbest and recognition of sacrifice - might play out.

\section{Compromise and the annual class trip}

In this example (based on a real-life situation; see also Weale, 2018; Guardian editorial, 2018) school students take a letter home to parents about a residential class trip. It sets out details of a coach trip to Paris staying in a youth hostel for 4 nights and costing $£ 500$ which can be paid in monthly instalments. It gives practical details about luggage and a list of essential clothes and emphasises the educational value of the trip: its cultural and historical aspects as well as the character-building benefits of widening horizons.

Following the letter, there is a meeting at school for students and parents at which various issues are raised. Some children and parents raise the point that they had been expecting a ski trip to Italy like last year's Year 7s had. A ski trip would have all the educational benefits of the Paris trip, they say, and is something parents as individuals would find harder to arrange. The teachers organising the trip explain that the ski trip would now cost more than last year, $£ 1,200$ at a minimum for a European destination. For a trip not directly related to the curriculum and more like a holiday, they felt that this was too much to ask families to pay. Very excited by this, some children claim that for $£ 1,200$ children at another local school are going to Uganda 'to get to know gorillas' and help build a school. This really is educational, they state. A teacher intervenes to say that the Uganda trip, a trip for Year 10s at the other school, is emphatically not on the table. Animated, though respectful, discussion continues, especially amongst the children, about the relative educational benefits of these 
trips. One of the teacher organisers says, equably but firmly, that the school wants to offer a trip which is affordable for everyone.

A group of parents and children is not joining in. There's a glum disquiet amongst them as they look again at the school letter. A woman points at some of the items on the 'essential clothes' list and says that getting new trainers and an anorak will make the trip even more expensive. Another woman in the group is worried and asks whether all children must go on the trip. What will happen if there are children who can't go? Will there be normal lessons?

The teacher organiser, realising that the cost of the trip is causing problems, stresses that, as it said in the letter, parents will not be expected to pay up front but can pay in instalments.

A couple of children, Amalia and Nikki, after a bit of mutual nudging, both raise their hands and say that they don't want to go. Their Mums each have two jobs, they both have younger brothers and sisters too and their families always run out of money before the end of the month. The instalment plan won't help them.

Another student, Omar, joins in to say he is worried that the trip which is, according to the letter, to be about 'bonding' and extending opportunities is causing discord and upset and embarrassing and excluding people. He points out that last year they had a great day trip to Ironbridge, so why not a day trip again? 
The discussion so far has shown some of the features of an attempt to reach a good compromise. First, people have been respectful and empathetic, treating each other as equals. Now, second, it becomes clear, at least to most of the group, that they 'may have to give up on the dream'. Not just 'getting to know gorillas' is out of the question but a whole class trip to Paris is not feasible, since this is way beyond the means of some families.

At this point, social imagination, sensitivity to the possibilities for flexibility and resourcefulness in finding ways round obstacles come into play. Various suggestions are made. A teacher organiser says that, in some schools, students finance the trip themselves by seeking sponsors and earning pocket money. But this is unfair too, Omar quickly points out, some children will easily get money from grandparents and aunts and uncles, whilst others won't be able to. Also, many children have to help in the house with chores and the idea that their parents could give them pocket money for that is just a joke.

Molly nods in vigorous agreement with Omar. Then she adds - in a lightbulb moment - that the fundraising needn't be down to individuals though, the whole class could fundraise to finance the trip. There's mumbling that this won't fund a ski trip and it sounds like a lot of hard work. Then other voices come in suggesting that if the whole point of the trip is to have a good time with your mates, show initiative and 'bond', this would be great. Fundraising and then seeing what kind of class outing could be funded with the proceeds could be, well, educational . . . . 
This is not, of course, the whole of the discussion(s) to find a compromise over the school trip destination and its funding. It is a small window onto a real-life school discussion which mirrors significant aspects of a democratic compromise in the political context. Thus far, it illustrates well the relevance of the practice of compromise to a dynamic citizenship education. Respect, as we have seen, and 'giving up on the dream' have come into play. Some students have lost out, those, for instance, whose families might perhaps have financed the Paris trip - or even a ski trip. There will be no mischievous glee that some people have lost out; even in this everyday context 'sacrifices' can be acknowledged. Importantly, it has also become clear that some principles, like fairness, cannot be 'relaxed' in a good compromise. The subsequent coalescing round a possibility which achieves a good for the whole community, even though it was nobody's first choice, affirms the values of the group as a caring community, as well as a fair one. The whole process suggests the possibilities the practice of compromise holds for helping students to cope collegially in a hands-on way and in an empathetic, hopeful and creative spirit with the inevitable conflicts, vicissitudes and sometimes disappointments involved in living in a community.

How to achieve in schools this dynamic political education with the practice of compromise at its heart? This suggestion takes for granted the professional wisdom that resides in teachers and the staffs of schools. Schools have administrative and organisational structures and spaces which call out for the contributions of students and parents. Judgements about where those are, how swiftly to move on attempts to involve students, and how most appropriately to do that, are best made by the teachers and other staff members who know their students and parents intimately. Ideally, in the world of the new public school, the development of responsive 
participatory structures in which the values and sentiments associated with the practice of compromise can be acquired and refined over time would also be supported by a robust in-service education. ${ }^{1}$

1. A longer and somewhat different version of the argument here was presented at the PESGB conference in March 2019.

Patricia White is an Honorary Senior Research Associate attached to the Centre for Philosophy of Education at UCL Institute of Education University of London. patricia.white@ucl.ac.uk

\section{References}

Bellamy, Richard (1999) Liberalism and Pluralism: Towards a politics of compromise, London: Routledge.

Benjamin, Martin (1990) Splitting the Difference: Compromise and Integrity in Ethics and Politics, Lawrence, Kansas: University Press of Kansas.

Berlin, Isaiah (1997) The Pursuit of the Ideal, in The Proper Study of Mankind, London: Chatto and Windus.

Carter, Will (2016) The strange neglect of political education - and how to revive it, The New Statesman 18 August 2016.

Department for Education (2015) Citizenship studies: GCSE subject content.

Franklin, Tom (2017) Citizenship lessons in schools more vital now than ever Online at https://www.theguardian.com/society/2017/jun/08/citizenship-lessons-inschools-more-vital-now-than-ever (Accessed 3 November 2018).

Guardian editorial (2018) 'School trips can open children's eyes, but they should be open to all', 23 November.

Gutmann, Amy and Thompson, Dennis (2012) The Spirit of Compromise: Why Governing Demands It and Campaigning Undermines It, Princeton: Princeton University Press.

Margalit, Avishai (2010) On Compromise: and rotten compromises, Princeton: Princeton University Press. 
Weale, Sally (2018) 'A school trip too far?' The Guardian, 22 November.

Wendt, Fabian (2016) Compromise, Peace and Public Justification: Public Morality Beyond Justice, Palgrave Macmillan.

White, Patricia (1983) Beyond Domination: An Essay in the Political Philosophy of Education, London: Routledge.

White, Patricia (1996) Civic Virtues and Public Schooling: educating citizens for democratic society, New York and London: Teachers College Press.

Williams, Bernard (1981) Conflicts of Values in his Moral Luck, Cambridge: Cambridge University Press.

Williams, Bernard (1985) Ethics and the Limits of Philosophy, London: Fontana Paperbacks. 